\title{
Research on the Reform and Practice of Business English Writing Under the Horizon of "Output Driving"
}

\author{
Liu Yi \\ School of Foreign Studies Anhui Sanlian University \\ Hefei Anhui, 230601
}

\begin{abstract}
Writing is a language export skill. Based on Wen Qiufang's "output-driven hypothesis", this paper probes into the reform and practice of business English writing teaching in higher vocational colleges, and points out that the course of business English writing in higher vocational colleges should set up the situation by changing the role of teachers from its own characteristics. Introducing the concept of "synthesis", advocating the means of "ability standard, project carrier" and opening up "output" channel, properly handling the input and output of teaching, and effectively cultivating the application ability of the students majoring in business English in higher vocational education. The operation skill and the thought innovation, comprehensively promotes the new century talented person quality education.
\end{abstract}

Keywords-Output Driven False; Business English Writing; Project Teaching

\section{INTRODUCTION}

The study of "input" and "output" has always been an important research topic in the field of second language acquisition. American linguists in the 1980s Crashen puts forward "language input theory", which holds that "the process of language acquisition is the process of constantly understanding and accepting language symbols and information; only when we really understand acceptable input can we really have language". "comprehensible input" has become an important concept in the theory of second language acquisition (SLA), which provides a new perspective for foreign language teaching in China. However, Crashen's language input theory emphasizes that output is only the natural result of input and has no direct effect on language acquisition. In 1985, Swain put forward the "output hypothesis", which holds that output is also of positive significance to language acquisition. Language input can play an important role in language acquisition, but it is only a carrier in the process of language acquisition and will not become the ultimate means of language acquisition. It is only through language expression and practice that the learner can truly possess the language rather than floating on the surface of the language. Although Swain fully affirms the positive significance of output in language acquisition, since its research background is French immersion teaching in Canada, it only emphasizes the conscious monitoring and checking of the output content by the learners themselves in the process of output. Therefore, it still can not solve the problem of how to monitor and evaluate English learners in the absence of target language.

There is no doubt that language learning is an alternating process of input and output. From the perspective of the law of learning, input is primary and the basis of output, especially in the context of non-target language learning, all practical activities should be based on a large number of language input as the premise. Similarly, only input and no output of language learning, facts and information will only stay in the stage of memory and can not be internalized, so as to achieve the purpose of language as a tool to express thoughts and feelings and convey information. However, for many years, Chinese English major curriculum and teaching practice have been emphasis on input, not output. How to realize the organic combination of input and output in foreign language classroom is an urgent problem to be solved. In 2008, Wen Qiufang, a well-known foreign language educator in China, put forward the "Export-driven hypothesis", which includes: first, from a psychological point of view, Output is more important than input in the development of foreign language competence. A learning process without output, [1] even with high quality input, has limited acquisition efficiency. Secondly, according to the needs of workplace English, it has more social function to develop students' speaking, writing and translating expressive skills than listening and reading receptive skills. Third, from the perspective of foreign language teaching, the output-oriented comprehensive teaching method is more effective than the single skill training method, and meets the needs of students' employment in the future. Starting from the traditional research of general English teaching, this paper deeply analyzes the application of "output-driven" hypothesis in professional English teaching, and insists on advocating the "output-oriented" comprehensive skill teaching method, that is, the comprehensive skill teaching method. The effective integration of skills training, knowledge broadening and thinking ability training has greatly encouraged English teachers to re-examine and orientate the teaching of English writing, and to set up the curriculum and the contents of the teaching. The reform and exploration of teaching mode and so on has certain reference significance. 


\section{THE ENLIGHTENMENT OF "OUTPUT-DRIVEN HYPOTHESIS" TO BUSINESS ENGLISH WRITING TEACHING IN UNIVERSITIES}

Business English writing course should deal with the relationship between input and output. Output drive makes input easy to be transformed into procedural knowledge, which is beneficial to the expansion of language system, and the teaching activity which combines output and input has more communicative authenticity. Therefore, business English writing classroom should insist on using output to drive input teaching, guide students to transform language input into language output in time, combine skill learning with knowledge broadening and thinking ability training organically, through more practice. More writing, more analysis and other means to effectively improve the comprehensive application of students' knowledge. In the process of talent training, it has become the consensus of education circles to follow the educational idea of "students as the main body". However, the implementation of this concept, is a long-term and arduous project. The design of curriculum system should focus on "students as the main body", first of all, how much students participate in the teaching process. Business English writing is a practical course. Only by organizing a large number of practical activities can students improve their comprehensive English skills. Teachers must change their roles and become the designers, guides, participants and facilitators of classroom activities. Only in this way can each student's consciousness of participating in classroom activities be aroused and the interaction between input and output be formed with the students. Actively improve its initiative, creativity and participation.

Situational approach was first established and proposed by English scholar Homby. Its essence is to provide sufficient strength for language function and activate the language knowledge by designing some situations and scenes of authenticity and quasi-authenticity. The basic purpose of business English writing in higher vocational colleges is to achieve the integration of teaching, learning and doing in order to improve students' written and professional abilities. However, compared with undergraduate students, the language base of higher vocational students is generally not high, and the content of business writing course itself is complicated, which requires teachers to give full play to their intelligence and intelligence, starting with creating situations and simulating real business activities. The combination of input and output, such as virtual roles and hypothetical tasks, makes writing fun and practical for students, and learning to do it by experiencing all the steps in a business activity. With the knowledge learned to complete the business communication process of writing tasks, to develop the ability of students to learn to use, for the future work to lay the foundation.

Based on the analysis of the theory of output-driven and output-promoting hypothesis, the author realizes the necessity of applying this model in the process of English teaching, so as to realize the effective combination of this mode with the teaching of English writing. For example, a certain college English teacher actively adopts this method in the teaching process, realizes the effective integration of reading teaching and practical teaching, and integrates the output driving and input promotion hypothesis into the writing teaching process in time, [2] thus realizing the integrated teaching. In the work of integrated teaching design, we should conscientiously follow the actual situation of the current teaching work and the learning progress of the students, learn more about the needs of the students, and then adopt the teaching method of combining reading and writing. It also helps to improve students' autonomous learning ability. In this process, students are required to strengthen the continuous consolidation and internalization of what they have learned, which is helpful for students to truly master what they have learned, and in this way to actively promote the further improvement of students' reading ability. It plays an important role in improving students' practical application ability, discrimination ability and artificial quality of English writing content. Output driving, output promoting hypothesis teaching mode is mainly reflected in: reading, writing, evaluation and so on, thus forming the integration of output, input, re-output, feedback and so on. The application of this integrated model in English writing teaching is analyzed in detail.

Among the five basic language skills, listening and reading are input skills; speaking, writing and translating are output skills. They are closely connected and interact with each other. Only on the basis of input can be output, but without output driven input, learners are less likely to acquire input. Business English writing is a means of expressing business communication in English written language to achieve various business purposes. It integrates business knowledge, English writing and business writing skills. Therefore, if teachers can integrate listening, speaking, reading, writing, translation and other activities in the teaching process, they can help students grasp the classroom teaching as a whole. In view of English writing teaching, it is necessary to introduce the concept of "synthesis" in the teaching practice, that is, to break the boundaries between the specialized skills classes and between the professional skills classes and the professional knowledge courses. Under a relatively complete business English curriculum system, other relevant courses, such as language basic curriculum, basic writing curriculum and professional core curriculum module, can be given due consideration to the teaching and training of writing skills. For example, Business English Reading can timely guide students to evaluate the content and form of business materials. On the other hand, the course of Business English Writing itself should be integrated with listening, speaking, reading, translation and other technical factors that integrate English and business English as far as possible. Improve the writing ability on the basis of improving the comprehensive ability.

Business English writing is a highly skilled course, which needs the combination of study and use to promote learning. Only in this way, students can continuously enhance their competitiveness in seeking employment, recognize the situation and enhance their influence in English learning. The classroom time for business English writing in higher vocational colleges is very limited. How to maximize In order to cultivate the practical operation ability of higher vocational students under the real situation, every teacher has the responsibility and obligation to actively open up channels and strengthen the writing practice inside and outside the school, 
which not only tests the knowledge learned by students, but also urges the students to perfect and innovate in practice. The "output" channel in the school can take the writing competition as an opportunity to form a good writing environment and promote the students' English application ability as a whole. [3] The thesis writing of business English major in higher vocational college is also an important link in teaching process. It can not only train the students' writing summarization ability and expression ability, but also train the students to use the knowledge they have learned to analyze and solve the practical problems. It is very important to improve the practical application ability, creative ability and innovation consciousness to improve the quality of talent training. Therefore, the major of business English in higher vocational colleges must attach importance to the graduation thesis of students, encourage students to collect and arrange materials actively, and combine professional teaching, practical experience and thesis writing organically. Business English writing course is employment-oriented and competency-based Therefore, it is necessary to strengthen the close contact with social related industries and enterprises, to find out a large foreign trade enterprise as an off-campus training base, to continuously establish a relatively stable training base outside school, and to give full play to the role of the off-campus training base in teaching. "it is only in the real work environment that students use the theoretical and practical skills they have learned in business English writing to complete front-line secretarial and business assistant work, so as to strengthen the business knowledge and skills they have learned," he said. It broadens the space and time of teaching activities, stimulates students' enthusiasm of autonomous learning, and makes business English writing a practical course.

\section{THE NeCESSITY OF THE REFORM OF THE COURSE CONTENT--"BuSINESS ENGLISH WRITING"}

\section{A. The Content of The Curriculum Pays Too Much Attention to The Objective Needs and Neglects the Development of Human Beings}

The purpose of the course is to single out the professional requirements that students majoring in international trade and business English should meet in their future foreign trade and business work, ignoring the dominant position of people in teaching activities. The content of the course neglects how to use the course as an information carrier to make students better understand and master knowledge and skills, and how to make students get vivid development in the process of learning. Making the curriculum a "what you say I do" regulation limits and restrains the release of human potential.In the course of setting up professional courses of English in higher vocational colleges, writing of business documents, writing of foreign trade English, and courses of business English correspondence and telegraphy are all compulsory courses for business English majors in higher vocational colleges, and they are also the core courses in the course structure of business English. Therefore, from the perspective of teaching system, it also reflects the importance of English writing for English majors. ExputDriven, Input-Promoter hypothesis: foreign language scientists believe that the English learning process is the simplification of tasks such as reading, audiovisual processing, memory, speaking, writing, and so on, in which reading and audiovisual processing belong to the input process. Writing belongs to the output process. In order to achieve the goal of improving the teaching level, the educator must first make clear the relationship between input and output, and master their meanings skillfully. Therefore, the study of the relationship between input and output is the core of foreign language studies, which has a profound impact on the teaching of business English writing. Input hypothesis refers to language learning beyond the scope of students' understanding.

\section{B. The Contents of The Course are Rigid,Lack of Room for Development, and Lack of Application}

The teaching contents and teaching materials are filled with common models and examples. There is no room for the design of curriculum contents, no opportunities for teachers to display their talents, and no way for students to produce new knowledge and skills in their experiences. For example, for the introduction of some letters, students like to recite lines, word by word, can not add or subtract. Students are also limited to rote memorization and sentence patterns when reviewing exams. As for the end of the memory can leave many traces, it is not known.At the same time, throughout the various English tests in higher vocational colleges, from English proficiency level A / B to CET-4 / CET-6, from CNBEC-BEC to TOELFGRE, from the Lingnan English Writing Competition to the National English Writing Competition for higher Vocational Colleges, almost all examinations, even competitions, are available. There is no lack of the English writing problem, which is more than enough to show that English writing skills are the students' English skills in higher vocational education. Essential skills in the learning process of a language course. Therefore, how to improve the "economic applicability" of English writing course in higher vocational colleges is particularly prominent and important.It is also a way to improve students' learning experience. According to the input hypothesis, educationalists have put forward the output hypothesis in time. Output hypothesis is a language that can help learners to learn second time. At the same time, the language has certain accuracy and fluency, but it requires learners to contact more comprehensible output content and to understand the output in time. In the process, The function of output-driven promotion hypothesis can be summed up as these points: 1) greatly improve the fluency of language and the degree of automation (2) check the correctness of hypothetical content (3) effectively enhance the subjective consciousness of learners (4) effectively cultivate learners' reflective ability. Under certain circumstances, actively controlling and deepening the language can effectively promote the continuous progress of the language, make it play an active guiding role in the teaching process, and at the same time, through the help of its own monitoring role, In order to realize the learners' selfimprovement, we can find out the deficiency of language in time. 


\section{HOW TO REFORM THE COURSE OF BUSINESS ENGLISH WRITING}

The content of the course focuses on professional knowledge and operational skills that are beneficial to the lifelong development of students, and ultimately promotes the curriculum of human development as an information carrier for the transformation of human potential into realistic quality. In this carrier, not only knowledge and skills are required, There must also be the process and methods of learning knowledge and skills, as well as the positive emotions, attitudes and values contained in the processes and methods, so as to promote people's moral, intellectual and technical qualities. The whole promotion of psychological quality and aesthetic quality. To be a comprehensive and harmonious person requires not only a wealth of professional knowledge and the skills and skills required for a particular profession, but also a strong sense of responsibility, a sense of mission, the ultimate concern and the pursuit of beauty. This is the task that vocational education should think about and accomplish.

In order to promote the development of human beings, the curriculum content of Business English Writing is changed from "knowledge text" and "skill text" to "Human Development" as the main line, designing and compiling the curriculum from multiple dimensions. We should not only attach importance to the construction of the goal and direction of curriculum content, but also to the construction of process and method, as well as to the construction of knowledge structure and skills, as well as the construction of nonintellectual factors. That is to say, the course content should be regarded as an information material, so that the students can improve their intelligence quality while improving their comprehensive quality through study, communication, practice and experience. In fact, the single transfer of knowledge and skills, often can not meet the needs of employers, this is because a single knowledge and skills, it is difficult to improve the overall quality of people. [4] Any professional role, first of all, should affirm the social role of human, and secondly, it is the special professional role. Therefore, the reform of the content of the course "Business English Writing" includes not only knowledge and skills as an indicator, but also the design of other indicators to accomplish this task-processes and methods, as well as feelings in processes and methods. The influence of attitude and values can promote and realize the harmonious development of human beings.

Combining writing skills and writing knowledge with practical business knowledge and business knowledge, taking into account the cultural differences between China and other countries, as well as the objective requirements of modern social lifestyles and modern concepts, Combining writing skills and writing knowledge with practical business knowledge and business, students' practical business communication ability will be improved. Since the course content of Business English Writing is based on professional knowledge and operational skills that are beneficial to students' lifelong development, and ultimately promotes the improvement of students' comprehensive quality, then the course content should not be based on reading model text and reciting examples. After transforming the educational thought of imparting knowledge and giving priority to general education to improving the quality of students and paying attention to cultivating students' ability and developing students' individuality, The teaching content of the course should also be transformed into how to communicate effectively in different situations. The content of the course involves not only business English writing, but also many fields of real life, which enable students to learn from rote to use, and to train their analytical and problem-solving abilities. For example, in the cover letter and resume writing section, the discussion of the whole process of recruiting talent by employers enables students to fully understand what kind of cover letter and resume are effective. Then write cover letters and resumes for different target readers, and then get interested and confident to practice.

Attach importance to the research and comprehensiveness of the curriculum content, any course content should leave a certain space for the students' study and development, let him We have the opportunity to explore and create new knowledge and skills through our own exploration and experience. One is to introduce inquiry learning into the curriculum to provide students with the opportunity and space to study; the other is to carry out comprehensive practical activities. For example, if we want to solve problems effectively, we must make analysis and research, use cultural background and business knowledge, and combine theoretical knowledge with practice. The course content of Business English Writing emphasizes the integration of knowledge content of different disciplines, which refers to the integration of knowledge in cultural subjects as well as professional knowledge. For example, the sales letter in Business English Writing deals with "Marketing" and "Psychology", and the inquiry letter relates to "International Trade practice" and the current international political and economic situation. The content of the course emphasizes the integration of cultural knowledge and professional knowledge, and realizes the transfer of students' learning. The theory and practice of learning transfer tell us that one kind of learning has different degrees of influence on the other learning, so as to improve the learning effect as a whole.

The choice of teaching materials should be "in line with each other". The textbook should be based on the needs of learners and attach importance to the application value of language. The course of English writing in higher vocational colleges should not only take full account of the characteristics of English education in higher vocational education, but also take into account the actual characteristics and level of each class of students, according to the levels and requirements of higher education. Difficult and moderate, in line with higher vocational students improve their English writing level of the recent development area. At the same time, the choice of teaching materials should also reflect the theory education to serve the practical application, in order to cultivate the suitable corresponding talents for the vocational or technical posts that accord with the characteristics of higher vocational education. Classroom teaching methods are "lively and interesting". English writing is a basic applied skill for English majors in higher vocational colleges. However, many teachers still use the traditional teaching method: teaching writing skillsanalyzing the writing model-requiring students to imitatestudents practice-comment after class-homework correction. We can not deny that this teaching method is practical and 
convenient for students to master the format. However, because of the wide range of English writing teaching, content and teaching style. However, the traditional teaching method is too single, the teachers teach too much and the students are less active. Because of the limitations, the teaching effect of English writing is not satisfactory.

The teaching of English writing is helpful for students to master English listening, speaking, reading, writing and so on. It can help students understand the skills of English writing in classroom learning, which is also an educational training for students in learning strategies. Therefore, we should pay more attention to the mode of output driving in writing teaching, and realize the timely change of teaching methods. In the process of business English writing teaching, we must give priority to students' needs and give the best expression to the status of students as the main body. At the same time, it encourages students not to be afraid of mistakes, to dare to speak, to realize the effective combination of listening and speaking, and to record key words and news events in time. Not only that, students should also actively cooperate with their teachers. For example, under the teacher's correct guidance and education, they should consciously and wholeheartedly devote themselves to the writing teaching process, timely and timely. Comparing with the traditional English teaching mode, it has more autonomy and independence, which can stimulate the students' learning desire to the greatest extent and realize the targeted teaching, thus greatly enhancing the effectiveness of the teaching of writing.

\section{CONCLUSION}

Business English writing takes the cultivation of business English application ability as the core, highlights the main position of the students, and realizes the integration of teaching, learning and doing. Therefore, how to effectively realize the combination of classroom teaching and practical activities and explore and develop the business English writing course with its own characteristics is particularly important. Under the guidance of "output-driven" hypothesis, the basic task of business English writing teachers is to actively design teaching activities, guide students to absorb and internalize the knowledge they have learned, and encourage students to think positively. Constantly reflect on their own language output, finally through their own efforts to complete the reconstruction of knowledge upgrade.

\section{ACKNOWLEDGMENT}

Fund Projects: This thesis is the stage research results of Anhui Provincial quality engineering project of Anhui Sanlian University--Teaching Reform Project--Business English Writing (Item Number:2016zlgc011), Provincial Major Teaching and Research projects--A Study on the Innovation of College English Curriculum System and Talent training Model in the Transformation Period of Colleges and Universities (2016jyxm0341) and Famous Master Atelier (2016msgzs028).

\section{REFERENCES}

[1] Chen Wenkai. A study on the Teaching Reform of English Major Writing based on output driven hypothesis [J]. Journal of Henan Institute of Education

[2] Han Ning. Teaching Reform and practice of Business English Applied Writing in higher Vocational Colleges [J]. The shopping mall is modernized in 2009.

[3] Yu Shanshan. The experiment and Exploration of College English Teaching Reform-based on the Theory of Export-Driven-InputProduction hypothesis [J]. Journal of Changsha University of Science and Technology: social Sciences Edition, 32: 134-138.

[4] Sun Chao. Output-Driven-Input-Driven hypothesis: its Application in Business English Writing Teaching [J]. Journal of Qiqihar University: philosophy and Social Sciences, 20166: 186-188. 